An International Journal of Language, Literature and Gender Studies (LALIGENS)

Ethiopia

Vol. 3 (2), Serial No 8, May, 2014:126-145

ISSN: 2225-8604(Print) ISSN 2227-5460 (Online)

http://dx.doi.org/10.4314/laligens.v3i2.8

\title{
TONAL PATTERNS OF ENGLISH SYLLABLE STRUCTURE BORROWED INTO YORUBA
}

OJO, GEORGE ADEKUNLE, Ph.D.

Department of English and Literary Studies

Ekiti State University

Ado-Ekiti, Nigeria

$+2348030785590$

E-mail: georgeade4life@yahoo.com

\begin{abstract}
This paper investigates the patterns of tone inherent in foreign lexical items when they are borrowed into the Yoruba language with a particular focus on the highest ranked tonal patterns. The Yoruba language which is a tonal language is one of the three foremost indigenous languages in Nigeria; therefore, its early contact with English was not a coincidence. The data for the study are elicited from news items on local media houses, supermarkets and street hawkers. These data sources were chosen because they are believed to possess current information on the foreign societies. Analysis of data reveals that HLL tonal pattern with $26.81 \%$ is highly ranked among other tonal patterns of borrowed words. The implication of this is that,
\end{abstract}


words with High-Low-Low tonal pattern are the most common foreign words found in Yoruba. This tonal pattern is the most frequent in the process of borrowing because it corresponds to most of the English words present in Yoruba.

\section{Introduction}

It is stating the obvious that all languages vary their pitch to achieve different meaning. How each of the languages uses variations in pitch may not necessarily be uniform. For instance, the way English varies its pitch is quite different from Yoruba. Therefore, this paper answers the question of how pitch is represented in the adaptation of English words that are borrowed into Yoruba. We shall discover that the information about linguistic pitch is represented in terms of tones, and that tone, on the one hand, and vowels and consonants, on the other, are arranged on separate, parallel structural tiers (Durand 1992). Based on our data, the auto segmental status of tone will be considered and it will be revealed that the tonal patterns of words can be lucidly presented in a two-tier model. Also, on the basis of Goldsmith's association convention and the no crossing constraint, this paper will show the way tones are associated with other elements in the phonological representation.

Tone in Yoruba is associated not only to pitch but also to length, muscular effort, phonation and vowel feature (see Green 2002). Three different phonemic tones are attested in Yoruba, viz: high $[\mathrm{H}]$, mid $[\mathrm{M}]$, low [L]. The high tone is "sometimes slightly breathy, relatively long, high intensity and high pitch often with a fall before a pause"; "mid tone have medium duration, high intensity, and high, often slightly falling pitch". The low tone has "medium duration, low intensity and low, often slightly rising pitch" (Chang 2004:16). Vowels in English loanword adaptations may carry any of these Yoruba tones. These tones are attested in the data as discussed in subsequent section.

It is also noteworthy that "within the SPE paradigm, tones were considered to be features on a par with other features" Durand 
(1992:243). Therefore, in describing a language (for example Yoruba) that possesses three distinctive level tones (i.e. high, mid, low), the following features are selected; $[\mathrm{H}]$ for high tone, $[\mathrm{M}]$ for mid tone and [L] for low tone to analyze the contrast between three syllables [bá] (where the acute accent means high), [bà] (where the grave accent means low) and [bā] (where the macron accent connotes a mid tone but this is not usually indicated). These tone marks are demonstrated in the matrix below:

Table: 1 Tone Matrix

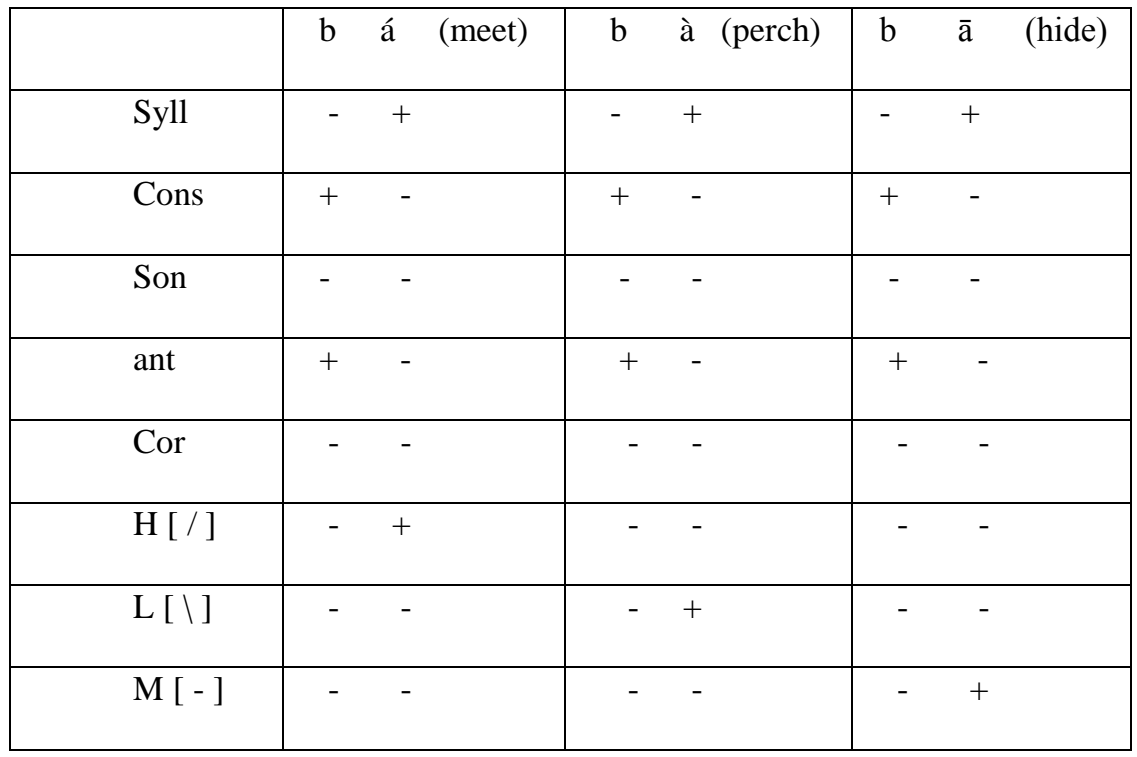

(Adapted from Durand 1992)

Tones are considered as features of vowels only in the above matrix. These features are irrelevant to the onset since they do not have no direct correlation with the onset, but all the same, this does not make them superior or more significant because other features (e.g. sonorant) which are not applicable to vowels are also considered. It is assumed in the matrix that tones are connected with the segments within syllables known as tone bearing units (TBU). These tone 
bearing units are vowels but other types of segments (such as alveolar nasal and alveolar lateral) can also bear tone (Durand 1992, Laniran 1992, Bamisaye 2004). These tones are demonstrated in actual English loans in Yoruba in this study.

It is however important to say that when these foreign words are borrowed into Yoruba, their syllable structures are re-defined. That is, a word that originally belongs to the class of monosyllabic or disyllabic words can change to disyllabic and trisyllabic words respectively when they enter the recipient language. Therefore, in this section, the treatment of their tonal patterns will be based on their newly acquired status.

\section{Co-Occurrence of High and Low Tones [HI]}

Some English words that were borrowed into Yoruba manifest the cooccurrence of both $\mathrm{H}$ (igh) and L(ow) tones. The manifestations of these tonal adaptations vary apparently depending on the types of the syllables that bear them, such as disyllabic words, trisyllabic words, quadri-syllabic words and polysyllabic words. The following tonal patterns have been observed in English loans in Yoruba, namely: [HL, HLL, HHL, HHHL, HHLL, HHHLL, and HHHHLL]. These patterns are so unique in that tones are combined systematically. That is, the occurrences of tones are in series depending on the types of the syllable structures on which they occur. For example, in polysyllabic words, there is a cluster of high tones followed by a cluster of low tones. Thus, we have [HHHLL].

It must also be noted that when English lexical items are borrowed into Yoruba, they violate the restriction on the occurrence of high tone on the first syllable of initial vowel (Ufomata 2004).

\section{Hl-Sequence on Disyllabic Words}

High and Low tones co-occur in disyllabic English words when they are adapted into Yoruba. This tonal pattern is demonstrated in actual words below. 
ENGLISH ENGLISH LOAN IN YORUBA

/ba:ba/

/kukə/

/teIlə/

/lojə/

/letə/

/leðə/

$/ \mathrm{b} \Lambda \mathrm{t}$ /

$/ \mathrm{ti}: \mathrm{t} \int \mathrm{\partial} /$

/o:də/

/rıbə/ [bábà]

[kúkà]

[telo]

[lojà]

[létà]

[lédà]

[botà]

[tífà]

[odà]

[robà]

\section{GLOSS}

'barber'

'cooker'

'tailor'

'lawyer'

'letter'

'leather'

'butter'

'teacher'

'order'

'rubber'

\section{Hll-Sequence on Trisyllabic Words}

Trisyllabic words manifest the co-occurrence of High-Low-Low [HLL] tones in foreign words when they are adapted into the recipient language. This is demonstrated in the examples below.

\section{ENGLISH}

/fæn/

/fIlm/

/gould/

/gəvənə/

$/ \mathrm{g} \Lambda \mathrm{m} /$

/bæg/

/ka:d/

/leis/

/korl/

/dgi:p/

/rais/
ENGLISH LOAN IN YORUBA

[fáànù]

[fîmù]

[góòlù]

[gómìnà]

[goomù]

[báàgì]

[káàdì]

[léèsì]

[koćli]

[ḑı̂pù]

[ráìsì]
GLOSS

'fan'

'film'

'gold'

'governor'

'gum'

'bag'

'card'

'lace'

'coil'

'jeep'

'rice'

\section{HHL-Sequence on Trisyllabic Words}

In this type of tonal adaptation, the occurrences of tones on syllable structures are $\mathrm{H}(\mathrm{igh})-\mathrm{H}(\mathrm{igh})-\mathrm{L}(\mathrm{ow})$ [HHL]. This is in opposition to what obtains in H(igh) - L(ow) - L(ow) [HLL] sequence (see 5.2.1.2). This tonal pattern is attested in the data as demonstrated below. 


\section{ENGLISH}

/barblı//

/bred/

/draivə/

/freIm/

/gromə/

/grævl/

/vIdiou/

/pasta/

/treila/

/gri:z/
ENGLISH LOAN IN YORUBA

[bíbélì]

[búrédì]

[dírébà]

[fúrémù]

[gírámà]

[gíráfù]

[fídíò]

[pásíto]

[tírélà]

[gírísì]

\section{GLOSS}

'bible'

'bread'

'driver'

'frame'

'grammar'

'gravel'

'video'

'pastor'

'trailer'

'grease'

\section{HHHL-Sequence on Quadri-Syllabic Words}

Two types of quadri-syllabic tonal patterns are attested in the data. They are High-High-High-Low [HHHL] and High-High-Low-Low [HHLL]. This section discusses the former while the latter will be discussed under HHHL-Sequence on quadri-syllabic words, the occurrences of higher than low tone (it is three against one). Thus, high tone has the greatest proportion of the tonal distribution. This tonal pattern is described in various words below.

$\begin{array}{lcl}\text { ENGLISH } & \text { ENGLISH LOAN IN YORUBA } & \text { GLOSS } \\ \text { /eindzel/ } & \text { [áńgéli]] } & \text { 'angel' } \\ \text { /di:kən/ } & \text { [díákónì] } & \text { 'deacon' } \\ \text { /eksidəs/ } & \text { [Ésóódù] } & \text { 'exodus' } \\ \text { /kæpentə/ } & \text { [kákpéńta] } & \text { 'carpenter' } \\ \text { /kauntsələ/ } & \text { [kàńsćlo] } & \text { 'councillor' } \\ \text { /kəstəmə/ } & \text { [kəsítoma] } & \text { 'customer' } \\ \text { /lusifə/ } & \text { [lúsíférì] } & \text { 'Lucifer' } \\ \text { /praimərI/ } & \text { [púràmárì] } & \text { 'primary' } \\ \text { /pærədais/ } & \text { [páraádísè] } & \text { 'paradise' }\end{array}$

\section{HHLL-Sequence on Quadri-Syllabic Words}

Tones in High-High-Low-Low tonal pattern are evenly distributed, (i.e. double high tones and double low tones). This tonal feature is 
entirely different from the HHHL tonal feature discussed previously where high tone dominates the greater part of the quadri-syllabic words. Examples of this tonal pattern are shown below.

\begin{tabular}{|c|c|c|}
\hline ENGLISH & ENGLISH LOAN IN YORUBA & GLOSS \\
\hline /blok/ & [búləokì] & 'block’ \\
\hline /briklerjə/ & [bíríkìlà] & 'bricklayer' \\
\hline /bI $\left.\int \mathrm{pp}\right]$ & [bífoobù] & 'bishop’ \\
\hline /braj/ & [búroosi] & 'brush' \\
\hline$/ \mathrm{dr} \Lambda \mathrm{m} /$ & [dúrosmù] & 'drum' \\
\hline /gləub/ & [gìlóòbù] & 'globe' \\
\hline /gærədz/ & [gáreèdzì] & 'garage' \\
\hline /gælən/ & [gáloonù] & 'gallon' \\
\hline /kələdł/ & [koléc̀dłì] & 'college' \\
\hline /klæs/ & [kíláasì] & 'class' \\
\hline
\end{tabular}

\section{HHHLL-Sequence on Polysyllabic Words}

The distribution of tones in this type of polysyllabic word is a sequence of three high tones and two low tones. Therefore, the combination of High-High-High-Low-Low tones gives us a word with multiple syllables. This tonal pattern is demonstrated in the examples below.

\begin{tabular}{|c|c|c|}
\hline ENGLISH & ENGLISH LOAN IN YORUBA & GLOSS \\
\hline /əlbım/ & [álúboomù] & 'album’ \\
\hline /bændeIdz/ & [báńdéèdzì] & 'bandage' \\
\hline /ınvələp/ & [Énbílóòkù] & 'envelope' \\
\hline /fri:dom/ & [fìrìdoomù] & 'freedom' \\
\hline /glukəus/ & [gúlúkóòsì] & 'glucose' \\
\hline /dzenezız/ & [dzénćsíìsì] & 'Genesis' \\
\hline /mætres/ & [mátíráasì] & 'mattress' \\
\hline /mekənık/ & [mékáníìì] & 'mechanic' \\
\hline /negeitiv/ & [négetíìfù] & 'negative' \\
\hline
\end{tabular}




\section{HHHHLL-Sequence on Polysyllabic Words}

This is the occurrence of four high tones and two low tones in a polysyllabic word. This High-High-High-High-Low-Low [HHHHLL] tonal pattern is not commonly found in loanwords. There are only three instances in the data and they are demonstrated below.

\section{ENGLISH ENGLISH LOAN IN YORUBA}

\section{GLOSS}

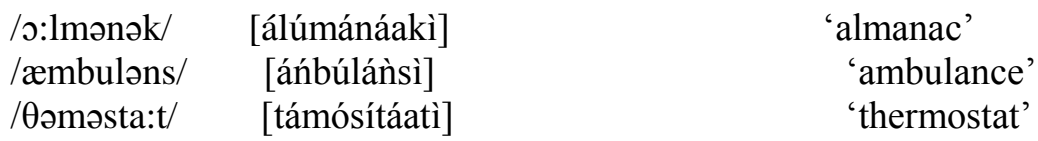

In the data, the breakdown of the High and Low tonal patterns of different categories is as follows:

Table 2: Loanword Adaptation of HL Tonal Patterns

\begin{tabular}{|l|l|l|}
\hline Tonal Pattern & Frequency & Percentage \% \\
\hline HL & 75 & 16.48 \\
\hline HLL & 122 & 26.81 \\
\hline HHL & 97 & 21.31 \\
\hline HHHL & 23 & 5.05 \\
\hline HHLL & 97 & 21.31 \\
\hline HHHLL & 37 & 8.13 \\
\hline HHHHLL & 04 & 0.87 \\
\hline TOTAL & $\mathbf{4 5 5}$ & $\mathbf{1 0 0 \%}$ \\
\hline
\end{tabular}

Table 2 above represents the frequencies of tonal patterns in English words borrowed into Yoruba. From the approach of Optimality Theoretical analysis, the most commonly occurring tonal pattern of English loanwords in Yoruba is High-Low-Low [HLL] with $122 / 455$ $(26.81 \%)$ of the instances in the data. Therefore, it is ranked the 
highest candidate. Second in rank is High-High-Low [HHL] and High-High-Low-Low [HHLL], the two are evenly distributed, they contribute ${ }^{97} / 455$ (21.31\%) instances while High-High-High-Low-LowLow [HHHHLL] is ranked the least in the tonal patterns with $4 / 455$ $(0.87 \%)$ of the instance therefore HHHHLL is ruled out. These tonal patterns are presented in the bar chart below.

Fig. 1: Bar Chart of HL Tonal Patterns

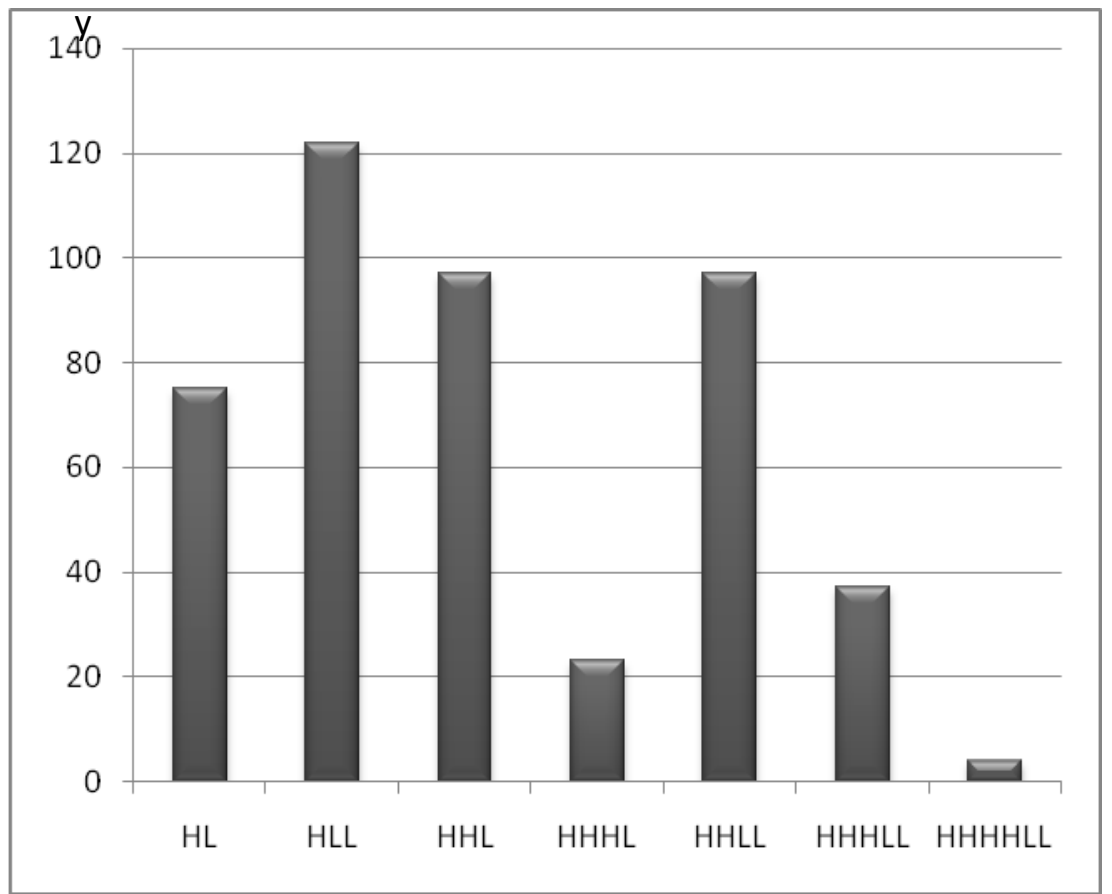

For better understanding, accuracy and appropriateness, I have also described the above HL tonal patterns in the pie chart below. The pie chart, which has a circular shape, has divided the tonal patterns into seven different sectors whose angles are proportionate to the frequencies of their manifestation as observed in the data. 
Fig 2: Pie Chart Representing HL Tonal Distributions

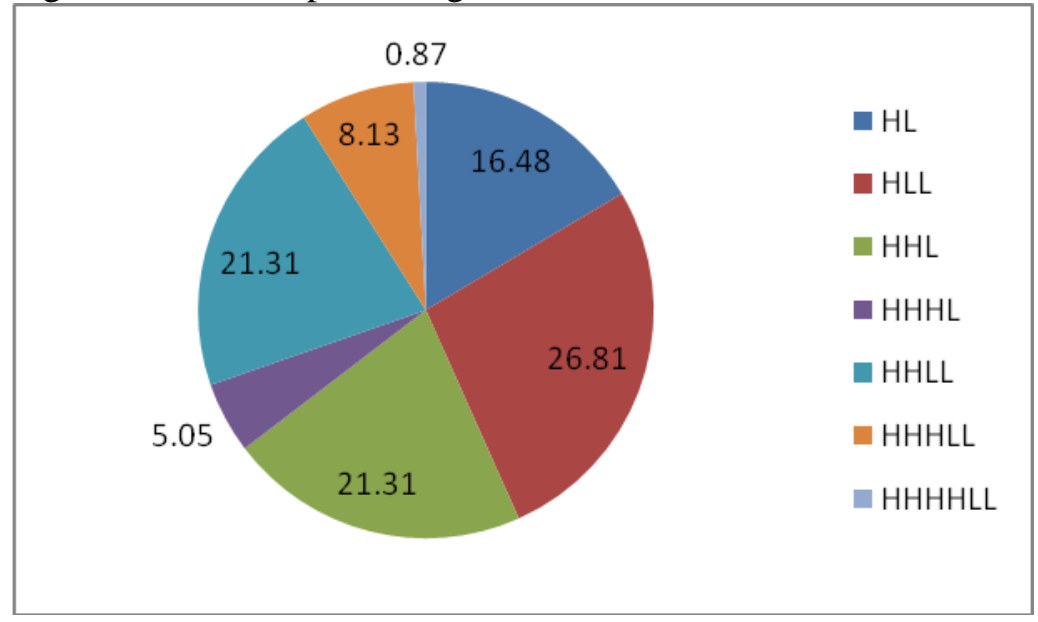

\section{Co-Occurrence of Low, High and Mid Tones}

Various patterns of low tone co-occurring with high and mid tones are treated in this section. The corpus of data collected reveals these various tonal patterns of English borrowed words into Yoruba. The tonal patterns are as follows: [LH, LLH, LHL, LHHL, LHLL, LLHL, LLHLL, LHHLL, and LLHHL].

\section{LH-sequence on disyllabic words}

When English lexical items are borrowed into Yoruba, Low-High tones co-occur. A few of this tonal pattern are obvious in the data and they are demonstrated in the examples below.

\section{ENGLISH ENGLISH LOAN IN YORUBA}

/berbi/

/gi:ta:/

/siga/ [bèbí]

[gìtá]

[sìgá]

\section{GLOSS}

'baby'

'guitar'

'cigar' 
Tonal Patterns of English Syllable Structure Borrowed into Yoruba

/KəuKəu/

[KOKO 」

$\cdot \operatorname{cocoa}$

\section{LHL-Sequence on Trisyllabic Words}

In this type of tonal pattern, high tone is situated between two low tones in such a way that high tone stands distinctly in between the two low tones. The instances of Low-High-Low tonal patterns are found in the examples given below:

ENGLISH

/skul/

/ripeə/

/pəteitəu/

/IreIzə/

/təma:təu]

/ritaiə/

/mulætəu/

/Imæm/

/rivalva/

/dairektə/

/bæzu:kə/
ENGLISH LOAN IN YORUBA

[ [ùkúrù]

[rìkpía]

[kpòtétò]

[ìresa]

[tòmátò]

[rìtája]

[mùlátò]

[ìmámù]

[rìfofa]

[daréto]

[basúka]

\section{GLOSS}

'school'

'repair'

'potato'

'eraser'

'tomato'

'retire'

'mullato'

'Imam'

'revolver'

'director'

'bazooka'

\section{LLH-SEQUENCE ON TRISYLLABIC WORDS}

The tonal pattern of this type is quadric-syllabic words is Low-LowHigh [LLH]. There are only three instances in the data. Examples of Low-Low-High tonal pattern are given below:

ENGLISH ENGLISH LOAN IN YORUBA

/brıðə/

/sistə/

/a:nt/ [bùrodá]

[sìsìtá]

[aǹtí]

\section{GLOSS}

'brother'

'sister'

'aunt'

\section{LHHL-Sequence on Quadri-Syllabic Words}

The tonal pattern of this type of quadri-syllabic word is Low-HighHigh-Low [LHHL]. It takes-off from a low tone, followed by two 
high tones and ends with a low tone. Examples of this tonal pattern are demonstrated below in actual words.

\begin{tabular}{|c|c|c|}
\hline ENGLISH & ENGLISH LOAN IN YORUBA & GLOSS \\
\hline /ædres/ & [adírésì] & 'address' \\
\hline /kælenda:/ & [kàléńdà] & 'Calendar' \\
\hline /kıləumitə/ & [kìlómítà] & 'kilometre' \\
\hline /mətənitI/ & [métánítì] & 'maternity' \\
\hline /oridzinəl/ & [orídzínà] & 'original' \\
\hline /ripcərə/ & [rìpíárà] & 'repairer’ \\
\hline /pəetıkjuləz/ & [pàtíkúlà] & 'particulars' \\
\hline /siment/ & [sìméńtì] & 'cement' \\
\hline /mæleırıə/ & [màléríà] & 'malaria' \\
\hline /ga:rəntə/ & [gàráńto] & 'guarantor' \\
\hline
\end{tabular}

\section{LHLL and LLHL-Sequence on Quadri-Syllabic Words}

There are two different types of tonal patterns of quadri-syllabic words in this type of adaptation, viz: Low-High-Low-Low and LowLow-High-Low. Though, the two patterns have common tones; the tones are distributed differently. These tonal patterns are demonstrated in the example below.

\begin{tabular}{|c|c|c|c|}
\hline ENGLISH & $\begin{array}{l}\text { ENGLISH LOAN } \\
\text { IN YORUBA }\end{array}$ & GLOSS & PATTERN \\
\hline /əla:m/ & [àláàmù] & 'alarm' & LHLL \\
\hline /dæməsk/ & [dàmáàsì] & 'damask' & LHLL \\
\hline /əbsэ:bə/ & [àbùssbà] & 'absorber' & LLHL \\
\hline /mædəm/ & [màdáàmù] & 'madam' & LHLL \\
\hline /rısi:t/ & [rìsîtì] & 'receipt' & LHLL \\
\hline /səlæd/ & [sàláàdì] & 'salad' & LHLL \\
\hline /ekspaıə/ & [ع́sìpájà] & 'expire' & LLHL \\
\hline /həutel/ & [òtźclì] & 'hotel' & LHLL \\
\hline /rivaıs/ & [rífàìsì] & 'revise' & LHLL \\
\hline /bræzıeə/ & [bèrèsíà] & "brassiere' & LLHL \\
\hline
\end{tabular}




\section{LLHLL, LHHLL andLLHHL-Sequence on Polysyllabic Words}

These tonal patterns are also grouped together because of the limited data in each of them. These tonal patterns manifest differently in various polysyllabic English lexical items when they are borrowed into Yoruba. Examples of these tonal patterns are demonstrated below in actual words.

\begin{tabular}{|c|c|c|c|}
\hline ENGLISH & $\begin{array}{l}\text { ENGLISH LOAN } \\
\text { IN YORUBA }\end{array}$ & GLOSS & PATTERN \\
\hline /ədvæns/ & [àlùbáǹsì] & 'advance' & LLHLL \\
\hline /blænkıt/ & [bùlánkéc̀tì] & 'blanket' & LHHLL \\
\hline /a:senbli/ & [àsćńbìlì] & 'assembly' & LHHLL \\
\hline /Inspektə/ & [ìnsìkpékíto] & 'Inspector' & LLHHL \\
\hline /æpəstl/ & [àkpósítélì] & 'apostle' & HLLLH \\
\hline /IletrIk/ & [غ̇léntíríkì] & 'electric' & HLLLH \\
\hline /lætrIn/ & [làtírînì] & 'latrine' & HLLHH \\
\hline /Igzekjutıv/ & [Èsćkútíìtù] & 'executive' & HLLLHH \\
\hline
\end{tabular}

\section{Co-Occurrence of Mid, Low and High Tones}

The tonal patterns in this group manifest variously in some English words when they are adapted into Yoruba. These tonal patterns takeoff from mid tone and co-occur with low tone and high tone in English lexical items when borrowed into the recipient language (Yoruba). The tonal patterns include [MH, MHL, MMH, MHHL, MMHL, MLHL, MHLL, MMHLL, MMHHL, MHHHLL, MMMHLL, MMMHHLL and MMHHLL]. These various patterns are discussed in subsequent sections.

\section{MH-Sequence on Disyllabic Words}

The co-occurrence of Mid-High $[\mathrm{MH}]$ is evident in disyllabic English words that are loaned to Yoruba. This is prominent in the pronunciation of Yoruba- English bilinguals and this is as a result of 
the influence of their mother tongue on English. Examples of these tonal patterns are demonstrated below.

ENGLISH ENGLISH LOAN IN YORUBA /pa:tI/

/fa:də/

/na:ni/

/gəulı/

/ka:kI/

/tælı/ [kpatí]

[fadá]

[naní]

[golí]

[kakí]

[talí]
GLOSS

'party'(social gathering)

'father'

'nanny'

'goalie'

'khaki'

'tally'

\section{MHL and MMH-Sequence on Trisyllabic Words}

These two tonal patterns are paired together because of their few instances in the data. They are treated together because they manifest similar syllable feature (i.e. three syllables). The instances of MidHigh-Low (MHL) and Mid-Mid-High [MMH] tonal patterns are described in actual words below.

$\begin{array}{llll}\text { ENGLISH } & \begin{array}{l}\text { ENGLISH LOAN } \\ \text { IN YORUBA }\end{array} & \text { GLOSS } & \text { PATTERN } \\ & \text { [tapólì] } & \text { 'tarpaulin' } & \text { MHL } \\ \text { /ta:pəlın/ } & \text { [oludé] } & \text { 'holiday' } & \mathrm{MMH} \\ \text { /holIdeI/ } & \text { [kirijó] } & \text { 'creole' } & \mathrm{MMH} \\ \text { /krıəu/ } & \text { [sinimo] } & \text { 'cinema' } & \mathrm{MMH} \\ \text { /sinımə/ } & \text { [sisitá] } & \text { 'sister' } & \mathrm{MMH} \\ \text { /sistə/ } & \text { (Rev.sister) } & \\ & \text { [refirí] } & \text { 'Referee' } & \mathrm{MMH}\end{array}$

\section{MMHL, MHHL, MLML and MHLL-Sequence on Quadri- Syllabic Words}

This is another group of tonal patterns that have similar syllable feature (i.e. four syllables). Though, they have different tonal patterns but the syllables that bear them all have mid tone as their initial tone. 
In other words, their initial syllable tone is corresponding with secondary stress in the Standard English. Examples of these tonal patterns are listed below.

\begin{tabular}{|c|c|c|c|}
\hline ENGLISH & \multicolumn{2}{|c|}{$\begin{array}{l}\text { ENGLISH LOAN } \\
\text { IN YORUBA }\end{array}$} & PATTE \\
\hline /teliviZən/ & [telifífo] & 'television' & MMHL \\
\hline /dzenereitə/ & [dzencréto] & 'generator' & MMHL \\
\hline /ımbrelə/ & [abùradà] & 'umbrella' & MLML \\
\hline /kəmifənə/ & [komífono] & 'commissioner' & MHHL \\
\hline /fənələdzI/ & [fonolodzi] & 'phonology' & MHHL \\
\hline /pəmeid/ & [kpoméèdì] & 'pomade' & MHLL \\
\hline /hospitl!/ & [osikpítù] & 'hospital' & MMHL \\
\hline /kætəpılə/ & [katakpílà & 'caterpillar' & MMHL \\
\hline /sailensə/ & [salćńsà] & 'silencer' & MHHL \\
\hline /fətəkəpi/ & [fotokokpì] & 'photocopy' & MMHL \\
\hline
\end{tabular}

\section{MMHLL-Sequence on Polysyllabic Words}

The tonal pattern of this type of polysyllabic words is Mid-Mid-HighLow-Low [MMHLL]. The pattern is so rhythmic in such a way that it can be divided into three metres (rhyme), i.e. [MM//H//LL]. The instances of this tonal pattern are predominant in English lexical items borrowed into Yoruba. Some of the examples are demonstrated in actual words below.

\begin{tabular}{|c|c|c|}
\hline ENGLISH & ENGLISH LOAN IN YORUBA & GLOSS \\
\hline /kerəusi:n/ & {$[$ karofînì̀ $]$} & 'kerosine' \\
\hline /biskit/ & [bisikîtì] & 'biscuit' \\
\hline /kreion/ & [kerejoonù] & 'crayon' \\
\hline /megəfəun/ & [megafóònù] & 'megaphone' \\
\hline /petrəl/ & [kpetiróòlù] & 'petrol' \\
\hline /kəukein/ & [kookéènì] & 'cocaine' \\
\hline /vəslın/ & [fasilînnì] & 'Vaseline' \\
\hline /aıdi:n/ & [ajodàìnì] & 'iodine' \\
\hline /kənfo:t/ & [konfootì] & 'Comfort' \\
\hline /tfəkəleit/ & [ Jokoléètì] & 'chocolate' \\
\hline
\end{tabular}


/dekəreit/

[dekoréètì]

'decorate'

\section{Multifarious Tonal Occurrences on Polysyllabic Words}

The remaining polysyllabic tonal patterns in the data are grouped together in this section; they are treated together because of the prefix (poly) that unites them together and for the fact that each of them has a few instances in the data. These tonal patterns include [MMMHHLL, MMHHLL, MMMHLL, MHHHLL, MMHHL and MMMHL]. They are variously demonstrated in the examples below.

\section{ENGLISH ENGLISH LOAN GLOSS PATTERN
PNO IN YORUBA}

/əlu:minəm/ [alumíníomù]

/eərəpleın/ [Erokpúléènì]

'aluminum'

MMHHLL

leərəplein/ [Erokpúléèni $]$

'aeroplane'

MMHHLL

/כ:təmətık/ [כtomátîkì]

'automatic'

MMHHLL

/tændzəri:n/ [tandzarînì]

'tangerine'

MMMHLL

/fətəgrəfə/ [fjtogíráfà]

'photographer' MMHHL

/fətəlaizə/ [fataláísà]

'fertilizer'

MMHHL

/græməfəun/ [giramofóònù]

'gramophone'

MMMHLL

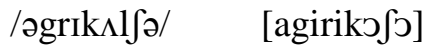

'agriculture'

MMMHL

Table 3 below summarizes the statistics of English lexical items bearing all the tonal patterns that I discussed above.

Table 3: Multifarious Tonal Adaptation of Polysyllabic Words

\begin{tabular}{|l|l|l|}
\hline Tonal Pattern & Frequency & Percentage \\
\hline LH & 08 & 5.55 \\
\hline LLH & 03 & 2.08 \\
\hline LHHLL & 08 & 5.55 \\
\hline LHL & 16 & 11.11 \\
\hline LML & 01 & 0.69 \\
\hline LHHHL & 02 & 1.38 \\
\hline LHHL & 13 & 9.02 \\
\hline
\end{tabular}




\begin{tabular}{|l|l|l|}
\hline LHLL & 15 & 10.41 \\
\hline LLHL & 04 & 2.77 \\
\hline LLHLL & 04 & 2.77 \\
\hline LLHHL & 02 & 1.38 \\
\hline MH & 03 & 2.08 \\
\hline MMMHL & 01 & 0.69 \\
\hline MHL & 02 & 1.38 \\
\hline MMH & 06 & 4.16 \\
\hline ML & 03 & 2.08 \\
\hline MHHL & 04 & 2.77 \\
\hline MMHL & 17 & 11.80 \\
\hline MLML & 01 & 0.69 \\
\hline MHLL & 02 & 1.38 \\
\hline MMHLL & 19 & 13.19 \\
\hline MMHHL & 03 & 2.08 \\
\hline MHHHLL & 01 & 0.69 \\
\hline MMMHHLL & 02 & 1.38 \\
\hline MMMHHLL & 02 & 1.38 \\
\hline MMHHLL & 02 & 1.38 \\
\hline TOTAL & $\mathbf{1 4 4}$ & $\mathbf{1 0 0}$ \\
\hline
\end{tabular}

From the table above, the highest ranked tonal pattern is [MMHLL] with ${ }^{19} / 100$ (13.19\%) of the instances. Second in rank is [MMHL] with ${ }^{17} / 100$ (11.80) followed by [LHL] with ${ }^{16} / 100$ (11.11). Five tonal patterns tied in that each of them scored ${ }^{01} / 100$ (0.69) of the total instances in the data. Therefore, they are least ranked, hence, they are ruled out. The tonal patterns are; [LML], [LHHLL], [MMMHL], [MLML] and [MHHHLL].

\section{Conclusion}

It is obvious from the analysis of data that the correspondence of tone and stress in language contact demands a critical examination. There is a clear indication that when foreign and local languages come in contact, these two phenomena play key roles in the production of words. 
It is evidently clear that language contact brings about a change in the status of lexical items. For instance, a foreign monosyllabic word becomes a disyllabic word when adapted in Yoruba. This is always so because local languages (such as Yoruba) do not exhibit stress and as a result, it is usually being replaced by tone (a feature of local languages). When this happens, an English word with only one syllable can become a Yoruba word with two syllables

It is also noteworthy that out of the various outputs of English words processed in Yoruba; those with HLL patterns constitute the majority with $26.81 \%$ instances. This percentage shows that the number of foreign lexical items borrowed into Yoruba is very far from the average. This portends that there are lots of English words still struggling to flow into Yoruba, especially, in this torrent modern technological development. And not only that, it is surprising that with the long contact between these two languages, only a few foreign lexical items could be said to have fully gained ground in Yoruba grammatical structure.

\section{References}

Adeniyi, Harrison \& Atolagbe, Bukola (2004). "Vowel Harmony in Nigerian English: A Non-Linear Approach" In Awonusi, S \& Babalola, E.A. (eds) The Domestication of English Language in Nigeria: A Festschrift in Honour of Abiodun Adetugbo. Lagos: University of Lagos Press.

Akinlabi, Akinbiyi (1985). Tonal Underspecification and Yoruba Tones. Ph.D Dissertation. University of Ibadan.

Arnold, G. F. (1957). "Stress in English Words". Lingua, Vol.6, No.4 pp. 221-267

Awobuluyi, Oladele (1978). Essentials of Yoruba Grammar. Ibadan: Oxford University Press. 
Awoniyi, T.A. (1978). Yoruba Language in Education. London: Oxford University Press.

Bamgbose, Ayo (1990). Fonoloji ati Girama Yoruba. Ibadan: University Press Limited.

Bamisaye, T. O. (2004). "Tone in African Languages" in Bamisaye (ed) An Integrated Study in Language and Society I. Lagos: Majab Publishers (pp 71-89).

Bamisaye, T. O. (2006a). "Autosegmental Analysis of Tone in Nigerian English" In UNAD Studies in Language and Literature Vol.2 pp.30-38

Durand, Jacque (1992). Generative and Non-Linear Phonology. New York: Longman.

Dustan, E. (1969). Twelve Nigerian Languages. Oxford: Oxford University Press.

Goldsmith, John (1976). Autosegmental Phonology. Indiana: University Linguistic Club.

Goldsmith, John (1990). Autosegmental and Metrical Phonology. Oxford: Blackwell

Green, Antony Dubach (2002). Word, Foot and Syllable Structure in Burmese. Ms: University of Potsdam.

Gussenhoven, Carlos (2004). The Phonology of Tone and Intonation. Cambridge: Cambridge University Press.

Halliday, M.A.K. (1967). Intonation and Grammar in British English. The Hague: Mouton.

Hyman, Larry \& Schuh, R. (1974). Universals of Tone Rules: Evidence from West Africa. Linguistic Inquiry 5, 1 pp.81-115

Ladefoged, Peter (1974). Preliminaries to Linguistic Phonetics. Chicago and London: University of Chicago.

Laniran, Y.O. (1992). Intonation in Tone Languages: The Phonetic 
Implication of Tones in Yoruba. Ph.D. Dissertation of Cornell University.

Laniran, Y.O. \& Clements, G.N. (2003). "Downstep and High Raising: Interacting Factors in Yoruba Tone Production". Journal of Phonetics, Vol. 31, pp. 203-250

Lee, Dongmyung (2009). The Loanword Tonology of South Kyungsang Korean. Ph.D. Dissertation. Indiana University

Pike, K. L. (1948). Tone Languages: A Technique for Determining the Numbers and Type of Pitch Contrasts in a Language with Studies in Tonemic Substitution and Fusion. Ann Arbor: University of Michigan Press.

Pulleyblank, Douglas (1986). Tone in Lexical Phonology. Dordrecht: Reidel Publishing Company.

Pulleyblank, Douglas (2004). A Note on Tonal Markedness in Yoruba. Phonology 21, pp. 409-425. 